\title{
Correction to: How relevant are social costs in economic evaluations? The case of Alzheimer's disease
}

\author{
L. M. Peña-Longobardo ${ }^{1}$ (I) $\cdot$ B. Rodríguez-Sánchez ${ }^{1} \cdot$ J. Oliva-Moreno $^{1} \cdot$ I. Aranda-Reneo $^{1} \cdot$ J. López-Bastida $^{2}$
}

Accepted: 13 May 2021

(c) The Author(s) 2021

\section{Correction to: The European Journal of Health Economics (2019) 20:1207-1236 https://doi.org/10.1007/s10198-019-01087-6}

The article How relevant are social costs in economic evaluations? The case of Alzheimer's disease, written by L. M. Peña-Longobardo, B. Rodríguez-Sánchez, J. Oliva-Moreno, I. Aranda-Reneo and J. López-Bastida was originally published electronically on the publisher's internet portal (currently SpringerLink) on 24 July 2019 without open access. With the author(s)' decision to opt for open choice, the copyright of the article changed on 20 May 2021 to () The Author(s) 2021 and the article is forthwith distributed under the terms of the Creative Commons Attribution 4.0 International License (http://creativecommons.org/licenses/by/4. $0 /$ ), which permits use, duplication, adaptation, distribution and reproduction in any medium or format, as long as you give appropriate credit to the original author(s) and the source, provide a link to the Creative Commons license and indicate whether changes were made.

The original article has been corrected.

The original article can be found online at https://doi.org/10.1007/ s10198-019-01087-6.

\section{M. Peña-Longobardo}

luzmaria.pena@uclm.es

1 Faculty of Social Science and Law, University of Castilla-La Mancha, Talavera de La Reina, Spain

2 Faculty of Health Science, University of Castilla-La Mancha, Talavera de La Reina, Spain
Open Access This article is licensed under a Creative Commons Attribution 4.0 International License, which permits use, sharing, adaptation, distribution and reproduction in any medium or format, as long as you give appropriate credit to the original author(s) and the source, provide a link to the Creative Commons licence, and indicate if changes were made. The images or other third party material in this article are included in the article's Creative Commons licence, unless indicated otherwise in a credit line to the material. If material is not included in the article's Creative Commons licence and your intended use is not permitted by statutory regulation or exceeds the permitted use, you will need to obtain permission directly from the copyright holder. To view a copy of this licence, visit http://creativecommons.org/licenses/by/4.0/.

Publisher's Note Springer Nature remains neutral with regard to jurisdictional claims in published maps and institutional affiliations. 